\title{
Lysozyme/EDTA disodium salt and modified-atmosphere packaging to prolong the shelf life of burrata cheese
}

\author{
A. Conte, ${ }^{*} \dagger$ I. Brescia, ${ }^{*}$ and M. A. Del Nobile ${ }^{*} \dagger^{1}$ \\ *Istituto per la Ricerca e le Applicazioni Biotecnologiche per la Sicurezza e la Valorizzazione dei Prodotti Tipici e di Qualità, Università degli Studi \\ di Foggia, Via Napoli, 25-71100 Foggia, Italy \\ †Dipartimento di Scienze degli Alimenti, Università degli Studi di Foggia, Via Napoli, 25-71100 Foggia, Italy
}

\section{ABSTRACT}

To prolong the shelf life of burrata cheese, we evaluated the effects of lysozyme and EDTA disodium salt $\left(\mathrm{Na}_{2}\right.$-EDTA $)$ with or without modified-atmosphere packaging (MAP) conditions. In particular, 3 concentrations of enzyme were combined with packaging in air and under MAP $\left(95: 5 \mathrm{CO}_{2}: \mathrm{N}_{2}\right)$. The decline in quality of burrata cheese stored at $8^{\circ} \mathrm{C}$ was assessed by monitoring microbiological and sensory quality, in addition to $\mathrm{pH}$ and headspace composition. The combination of lysozyme $/ \mathrm{Na}_{2}$-EDTA and MAP prolonged cheese shelf life, especially at the highest lysozyme concentration. In particular, the tested strategy was effective against microbial spoilage phenomena that appeared to be the quality factor that determine product unacceptability. Key words: burrata cheese, active coating, modifiedatmosphere packaging, shelf life

\section{INTRODUCTION}

Burrata is a fresh cheese with a smooth surface and a sweet and buttery taste. The cheese is worked by hand and consists of a ball of pasta filata cheese that contains a pasta called stracciatella. Burrata is a typical product of the Apulia region of Italy and is generally produced from cow milk. Burrata is obtained by mixing milk, the acidified serum of the previous day's milking, and calf rennet to reach a $\mathrm{pH}$ around 6.1 to 6.2. Before wrapping, burrata is immersed for few minutes in brine for salting (Salvadori del Prato, 2001). Due to its high moisture and fat contents, burrata is very susceptible to microbial spoilage, especially under temperature abuse.

The potential of modified-atmosphere packaging (MAP) for extending shelf life has been demonstrated for various fresh milk-derived products (Floros et al., 2000; Papaioannou et al., 2007; Conte et al., 2009a; Del Nobile et al., 2009a). However, the success of cheese

Received October 25, 2010.

Accepted June 30, 2011

${ }^{1}$ Corresponding author: ma.delnobile@unifg.it packaging is dependent on several important parameters, such as the type of cheese, the use of starter cultures during production, its initial microbial contamination, and storage conditions (Del Nobile et al., 2009b). Therefore, proper study should be carried out for each specific dairy food. The gases normally used for MAP include $\mathrm{CO}_{2}, \mathrm{O}_{2}$, and $\mathrm{N}_{2}$. The most important gas from a microbiological standpoint is $\mathrm{CO}_{2}$, used alone or combined with $\mathrm{N}_{2}$ or $\mathrm{O}_{2}$, which inhibits the growth of many microorganisms, including spoilage bacteria (Daniels et al., 1985). Moir et al. (1993) demonstrated that a $40 \% \mathrm{CO}_{2}$ atmosphere inhibited the growth of Pseudomonas spp. inoculated into a creamed-style cottage cheese at 5 and $15^{\circ} \mathrm{C}$. Inhibition by $\mathrm{CO}_{2}$ was greater at the surface than in the interior part of the spreadable cheese and was more significant at lower temperatures; the interesting feature was the lack of any influence of MAP on flavor and $\mathrm{pH}$. Although MAP effects on microbial stability are reported in certain dairy foods, very little information dealing with sensory properties exists (Conte et al., 2009a; Del Nobile et al., 2009b), suggesting that further investigations on MAP applications are advisable.

Another approach to extend the shelf life of dairy products is the use of natural antimicrobial compounds. These substances may be used either during the main process steps or at the packing stage. Altieri et al. (2005) reported the use of a solution of lactic acid and chitosan directly in the production of mozzarella cheese to prolong product shelf life. Conte et al. (2007) demonstrated that lemon extract in the packaging of mozzarella could prevent product decay with a consequent prolongation of shelf life compared with the traditional system. Sinigaglia et al. (2008) also demonstrated that the shelf life of mozzarella could be prolonged by dissolving lysozyme and the disodium salt of EDTA $\left(\mathbf{N a}_{2}-\right.$ EDTA) in the packaging brine. Lysozyme is a lactic enzyme found in many natural systems, and it is used in cheese manufacture to prevent the growth of lactatefermenting and gas-forming Clostridia spp. (Crapisi et al., 1993). The antimicrobial spectrum of lysozyme can be enhanced when it is used with other substances, 
such as EDTA (Branen and Davidson, 2004; Sinigaglia et al., 2008), disodium pyrophosphate, pentasodium tripolyphosphate (Boland et al., 2003), caffeic acid, and cinnamic acid (Masschalck and Michiels, 2003). In addition, Conte et al. (2009a) successfully tested the effectiveness of an active coating containing lysozyme/ $\mathrm{Na}_{2}$-EDTA combined with MAP in prolonging the shelf life of fior di latte cheese.

To date, no studies are reported on burrata cheese. Therefore, the objective of this research was to evaluate the effectiveness of a combination of lysozyme/ $\mathrm{Na}_{2}$-EDTA and MAP to preserve burrata cheese quality. To this aim, microbiological, chemical, and sensory changes of cheeses stored at $8^{\circ} \mathrm{C}$ were monitored for $9 \mathrm{~d}$.

\section{MATERIALS AND METHODS}

\section{Sample Preparation}

Samples of burrata cheese (100 g) were purchased from the dairy plant "Posta la via" (Foggia, Italy) and immediately transported to the laboratory. The cheese was produced as follows: $6 \mathrm{~L}$ of sour cream was divided into 3 batches and $50 \mathrm{mM} \mathrm{Na} \mathrm{N}_{2}$-EDTA salt was added into each batch; after thorough mixing, $150 \mathrm{mg} / \mathrm{kg}$ (L150), $250 \mathrm{mg} / \mathrm{kg}$ (L250), and $500 \mathrm{mg} / \mathrm{kg}$ (L500) of lysozyme were added to the batches. Samples without active substances were used as controls (CON). Each cheese sample was then packaged in commercially available bags (Valco, Bergamo, Italy) with a thickness of $95 \mu \mathrm{m}$. The bags were produced by laminating a nylon layer and a polyolefin layer. The packaging has an oxygen transmission rate of $50 \mathrm{~mL} \cdot \mathrm{m}^{-2} \cdot 24 \mathrm{~h}^{-1}$ at 1 atm, measured at $23^{\circ} \mathrm{C}$ and $75 \%$ relative humidity. During packaging, atmospheric (air) and MAP conditions $\left(95 \% \mathrm{CO}_{2}\right.$ and $\left.5 \% \mathrm{~N}_{2}\right)$ were used; control samples without lysozyme were designated $\mathbf{C O N}-\mathrm{Air}$ and $\mathrm{CON}$ MAP, respectively. All samples were stored at $8^{\circ} \mathrm{C}$ for $9 \mathrm{~d}$. Determinations of microbial count, $\mathrm{pH}$, headspace gas composition, and sensory evaluation were carried out before packaging and thereafter at 1, 2, 5, 7, and 9 $\mathrm{d}$ of storage on different cheese samples.

\section{Microbiological Analyses}

About $20 \mathrm{~g}$ of burrata cheese was diluted in $180 \mathrm{~mL}$ of Ringer solution in a Stomacher bag and blended with a Stomacher Lab Blender (PBI, International Milan, Italy). Serial dilutions of homogenates were plated on the appropriate media in Petri dishes. The media and conditions used were as follows: plate count agar (Oxoid, Basingstoke, UK), incubated at $30^{\circ} \mathrm{C}$ for $48 \mathrm{~h}$ for total microbial count and at $4^{\circ} \mathrm{C}$ for $10 \mathrm{~d}$ for psychro- trophic microflora; de Man, Rogosa, and Sharpe agar (Oxoid), supplemented with cycloheximide $(100 \mathrm{mg} / \mathrm{L}$, Sigma, St. Louis, MO), incubated under anaerobiosis (Anaerogen Gas Pack, Oxoid) at $37^{\circ} \mathrm{C}$ for $48 \mathrm{~h}$ for lactic acid bacilli; yeast peptone dextrose agar (Oxoid), supplemented with chloramphenicol $(0.1 \mathrm{~g} / \mathrm{L}$, Oxoid $)$ incubated at $30^{\circ} \mathrm{C}$ for $48 \mathrm{~h}$ for yeasts and molds; violet red bile lactose agar (Oxoid) incubated at $37^{\circ} \mathrm{C}$ for $24 \mathrm{~h}$ for total coliforms; violet red bile glucose agar (Oxoid) incubated at $37^{\circ} \mathrm{C}$ for $24 \mathrm{~h}$ for Enterobacteriaceae; and pseudomonas agar base (Oxoid), with added SR103 E selective supplement (Oxoid) and incubated at $25^{\circ} \mathrm{C}$ for $48 \mathrm{~h}$ for Pseudomonas spp. Each microbial test was conducted twice on 2 different batches.

To quantitatively determine the microbial effectiveness of the investigated packaging systems, a reparameterized version of Gompertz equation was fitted to the experimental data, as reported in the work of Del Nobile et al. (2009b):

$$
\begin{gathered}
\log (N(t))=\log \left(N_{\text {max }}\right)-A \times \\
\exp \left\{-\exp \left\{\left[\left(\mu_{\text {max }} \cdot 2.71\right) \cdot \frac{\lambda-M A L}{A}\right]+1\right\}\right\} \\
+A \cdot \exp \left\{-\exp \left\{\left[\left(\mu_{\text {max }} \cdot 2.71\right) \cdot \frac{\lambda-t}{A}\right]+1\right\}\right\},
\end{gathered}
$$

where $N(t)$ is the viable cell concentration at time $t, A$ is related to the difference between the decimal logarithm of maximum bacterial growth attained at the stationary phase and decimal logarithm of the initial value of cell concentration, $\mu_{\max }$ is the maximal specific growth rate, $\lambda$ is the lag time, $N_{\max }$ is the microbial threshold value, $M A L$ is the microbiological acceptability limit [i.e., the time at which $N(t)$ is equal to $N_{\max }$, and $t$ is the storage time. No legislation is applicable to burrata cheese, and no information can be provided from the literature on target microorganisms for burrata cheese. Therefore, Eq. [1] was used to fit the microbial data related to Pseudomonas spp. and coliforms, which are considered the main spoilage microbial groups of similar fresh dairy cheeses, such as mozzarella and stracciattella (Conte et al., 2009a; Del Nobile et al., 2009b; Gammariello et al., 2008, 2009, 2010). As reported in the literature, the value of $N_{\max }$ was set to $10^{6} \mathrm{cfu} / \mathrm{g}$ for Pseudomonas spp. and $10^{5} \mathrm{cfu} / \mathrm{g}$ for coliforms.

\section{pH Determination}

The $\mathrm{pH}$ values on each sample were determined by direct reading with a $\mathrm{pH}$ meter (Crison, Barcelona, Spain). Each value was the average of measures recorded on samples from 2 different batches. 


\section{Headspace Gas Composition}

Before opening the cheese bags, headspace gas composition was determined by using a Checkmate 9900 gas analyzer (PBI Dansersor, Ringsted, Denmark). The volume taken from the package headspace for gas analysis was about $10 \mathrm{~cm}^{3}$. To avoid modifications in the headspace gas composition due to gas sampling, each package was used for only a single determination of the headspace gas composition. Two samples were used for each test.

\section{Sensory Analysis}

The sensory panel consisted of 6 trained judges who were previously trained in cheese profiling. Panel training sessions were performed to familiarize the assessors with the language and the products under investigation. The judges were given 1 burrata sample per day on 4 successive days. Practice sessions were held with a paper ballot bearing all the descriptors that were used during the regular evaluation sessions. The panelists evaluated burrata for color and external appearance as soon as they received a sample of cheese. They were then instructed to chew the sample and use their tongues to push it against the palate to perceive the flavor and consistency. The assessors were also asked to give information on the overall quality of burrata, considering this index as the mean value of all the other specific attributes. Unsalted crackers and water were provided in between samples for cleansing the panelists' palates. A 7-point unstructured line scale was used for each descriptor on the sensory ballot and the judges were instructed to place a mark on the scales according to their perception of the sensory attributes, bearing in mind that 4 represented the threshold for product acceptability (Corradini and Innocente, 2002; Conte et al., 2009a).

To quantitatively determine the efficiency of the proposed strategies on the preservation of sensory quality, a reparameterized version of Gompertz equation was fitted to the experimental data, as reported by Del Nobile et al. (2009b):

$$
\begin{gathered}
S Q(t)=S Q_{\min }+A^{Q} \times \\
\exp \left\{-\exp \left\{\left[\left(\mu_{\max }^{Q} \cdot 2.71\right) \cdot \frac{\lambda^{Q}-S A L}{A^{S A}}\right]+1\right\}\right\} \\
-A^{Q} \cdot \exp \left\{-\exp \left\{\left[\left(\mu_{\max }^{Q} \cdot 2.71\right) \cdot \frac{\lambda^{Q}-t}{A^{Q}}\right]+1\right\}\right\},
\end{gathered}
$$

where $S Q(t)$ is the burrata overall sensory quality at time $t, A^{Q}$ is related to the difference between the burrata overall sensory quality attained at the stationary phase and the initial value, $\mu_{\max }^{Q}$ is the maximal rate at which $S Q(t)$ decreases, $\lambda^{Q}$ is the lag time, $S Q_{\min }$ is the burrata overall sensory quality threshold value, $S A L$ is the sensory acceptability limit [i.e., the time at which $S Q(t)$ is equal to $\left.S Q_{\min }\right]$, and $t$ is the storage time. As reported beforehand, the value of $S Q_{\min }$ was set equal to 4 .

\section{Statistical Analysis}

The values of the microbial acceptability limit (MAL) and the sensory acceptability limit (SAL) of the investigated samples were compared by one-way ANOVA. The Duncan multiple range test, with the option of homogeneous groups $(P<0.05)$, was used to determine significance among differences. Statistica 7.1 for Windows (StatSoft Inc., Tulsa, OK) was used for this purpose.

\section{RESULTS AND DISCUSSION}

\section{Microbiological Quality}

Figure 1 shows the viable cell load of Pseudomonas spp. plotted as a function of storage time for samples stored in air and MAP. The curves were obtained by fitting Eq. [1] to the experimental data. As can be inferred from data in the figure, cheeses in both CON-Air and CON-MAP exceeded the MAL $\left(10^{6} \mathrm{cfu} / \mathrm{g}\right)$ within a few hours, reflecting the microbial quality of the raw milk (Gammariello et al., 2009). For samples containing the active substance and stored in air, no significant differences were recorded compared with the control samples, because the Pseudomonas spp. viable cell load of all cheese samples exceeded the MAL after 2 d of storage. On the other hand, relevant differences were observed among the samples containing the active compound and sealed under MAP. In particular, as can be inferred from Figure 1b, the samples with lower concentrations of lysozyme reached the MAL within $3 \mathrm{~d}$, whereas the L500-MAP sample had $<10^{6} \mathrm{cfu} / \mathrm{g}$ during the entire observation period. The fitting procedure allowed calculation of useful model parameters. In terms of maximal specific growth rate and lag time, very similar values were recorded when samples were compared. Slight differences were recorded in terms of the $A$ values (the difference between the decimal logarithm of maximum bacterial growth attained at the stationary phase and decimal logarithm of the initial value of cell concentration). In particular, burrata samples with lysozyme packaged under MAP showed the lowest values of $A$. Table 1 shows the MAL ${ }^{\text {Pseudomonas }}$ values. As can be observed, no statistically significant differences were found between the 2 control samples, CON-Air 
and CON-MAP. Burrata with the lowest 2 concentrations of lysozyme packaged in air also showed very low MAL values. For the samples stored under MAP, a synergistic effect was observed between MAP and the active substance, which became more pronounced with the increase in lysozyme concentration. For burrata samples with the highest lysozyme concentration, the MAL was never reached. According to other findings reported in the literature, the results of Table 1 confirm the effectiveness of MAP and further suggest the synergistic effect of MAP with the selected active substance, as reported by Conte et al. (2009a) in fior di latte cheese. In fact, due to its bacteriostatic effect, $\mathrm{CO}_{2}$ slows the growth of aerobic, gram-negative bacteria, such as Pseudomonas spp., by extending the lag phase and decreasing the growth rate during the logarithmic phase (Farber, 1991). Similar MAP effects have been reported by other authors for various types of cheese, including mozzarella and cameros cheese (Alves et al., 1996; Eliot et al., 1998; Gonzalez-Fandos et al., 2000).

Figure 2 shows the evolution of total coliforms, plotted as a function of storage time for air and MAP samples. As reported in this figure, some differences between the cheese samples were recorded under both
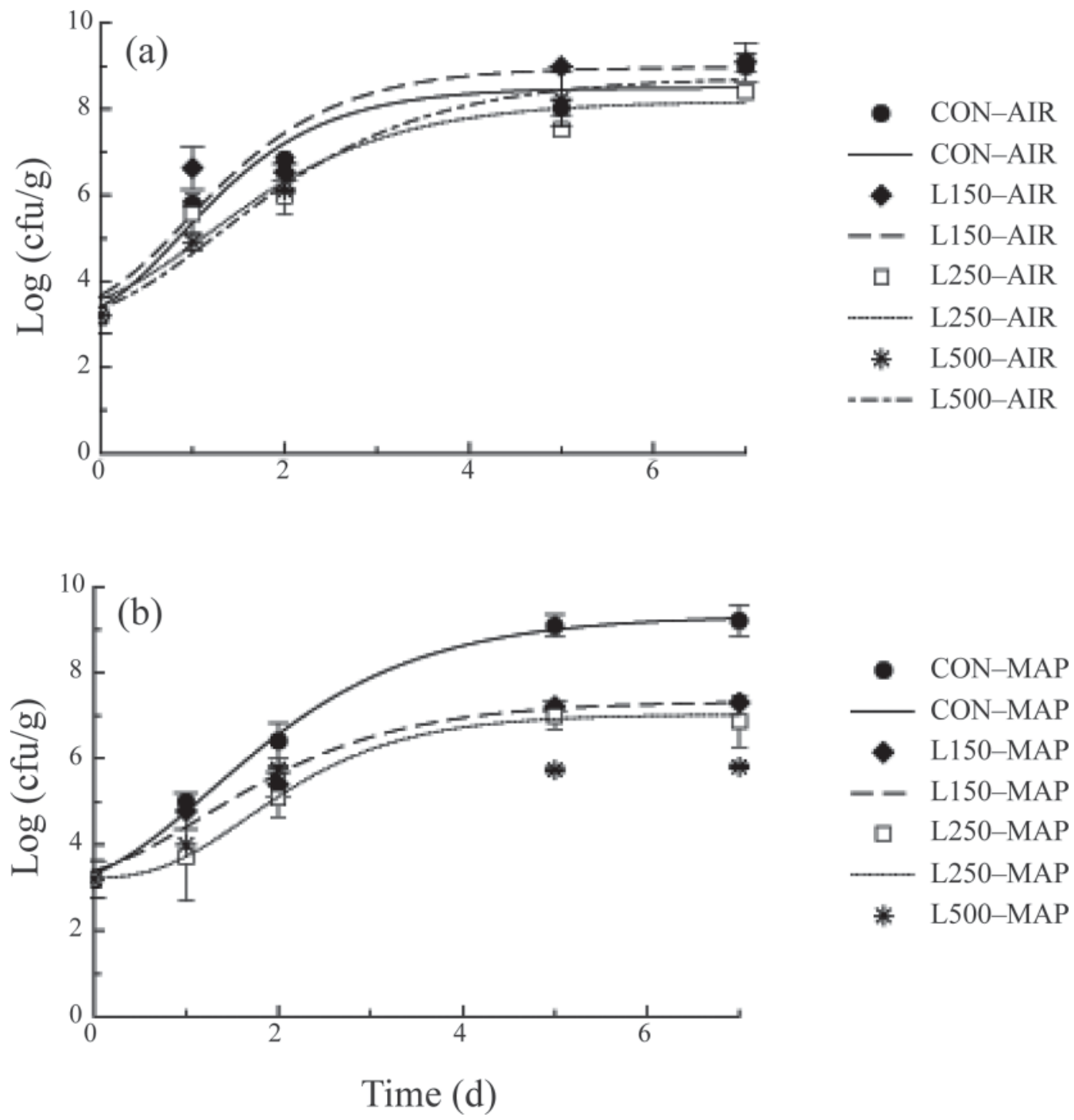

Figure 1. Pseudomonas spp. cell concentrations in burrata cheese packaged (a) in air and (b) under modified-atmosphere packaging (MAP) during the storage period. CON-Air $=$ control in air; CON-MAP $=$ control under modified-atmosphere packaging $(\mathrm{MAP}) ; \mathrm{L} 150$-Air $=$ burrata with $150 \mathrm{mg} / \mathrm{kg}$ of lysozyme packaged in air; L250-Air = burrata with $250 \mathrm{mg} / \mathrm{kg}$ of lysozyme packaged in air; L500-Air = burrata with 500 $\mathrm{mg} / \mathrm{kg}$ of lysozyme packaged in air; L150-MAP = burrata with $150 \mathrm{mg} / \mathrm{kg}$ of lysozyme packaged under MAP; L250 = burrata with $250 \mathrm{mg} /$ $\mathrm{kg}$ of lysozyme packaged under MAP; L500 = burrata with $500 \mathrm{mg} / \mathrm{kg}$ of lysozyme packaged under MAP. Data are presented with standard deviations; the curves are the best fit to the experimental data. 
Table 1. Shelf life (d; mean $\pm \mathrm{SD}$ ) of burrata samples, assumed as the lowest value among the calculated microbial and sensory acceptability limits ${ }^{1}$

\begin{tabular}{lcccc}
\hline Sample $^{2}$ & MAL $^{\text {Pseudomonas }}$ & MAL $^{\text {Coliforms }}$ & SAL $^{\text {Overall acceptability }}$ & Shelf life $(\mathrm{d})$ \\
\hline CON-Air & $1.3 \pm 0.2^{\mathrm{ab}}$ & $2.2 \pm 0.4^{\mathrm{a}}$ & $5.9 \pm 0.4^{\mathrm{c}}$ & $1.3 \pm 0.2^{\mathrm{ab}}$ \\
L150-Air & $1.2 \pm 0.4^{\mathrm{a}}$ & $2.5 \pm 0.1^{\mathrm{ab}}$ & $4.5 \pm 0.3^{\mathrm{ab}}$ & $1.2 \pm 0.4^{\mathrm{a}}$ \\
L250-Air & $1.8 \pm 0.4^{\mathrm{bc}}$ & $>9$ & $4.0 \pm 0.4^{\mathrm{a}}$ & $1.8 \pm 0.4^{\mathrm{abc}}$ \\
L500-Air & $1.8 \pm 0.2^{\mathrm{c}}$ & $3.8 \pm 0.7^{\mathrm{b}}$ & $4.9 \pm 0.4^{\mathrm{b}}$ & $1.8 \pm 0.2^{\mathrm{c}}$ \\
CON-MAP & $1.7 \pm 0.1^{\mathrm{abc}}$ & $2.9 \pm 0.1^{\mathrm{ab}}$ & $6.3 \pm 0.3^{\mathrm{c}}$ & $1.7 \pm 0.1^{\mathrm{bc}}$ \\
L150-MAP & $2.3 \pm 0.3^{\mathrm{d}}$ & $>9$ & $5.1 \pm 0.4^{\mathrm{b}}$ & $2.3 \pm 0.3^{\mathrm{d}}$ \\
L250-MAP & $2.8 \pm 0.2^{\mathrm{d}}$ & $>9$ & $4.4 \pm 0.3^{\mathrm{ab}}$ & $2.8 \pm 0.2^{\mathrm{d}}$ \\
L500-MAP & $>9$ & $6.3 \pm 1.7^{\mathrm{c}}$ & $4.8 \pm 0.3^{\mathrm{b}}$ & $4.8 \pm 0.3^{\mathrm{e}}$ \\
\hline
\end{tabular}

${ }^{\mathrm{a} e}$ Data in each column with different superscript letters are significantly different $(P<0.05)$.

${ }^{1} \mathrm{MAL}^{\text {Pseudomonas }}=$ microbiological acceptability limit (days) for Pseudomonas spp.; MAL ${ }^{\text {Coliforms }}=\mathrm{MAL}$ (days) for coliforms; SAL = sensory acceptability limit (days).

${ }^{2} \mathrm{CON}$-Air $=$ control in air; CON-MAP $=$ control under modified-atmosphere packaging $(\mathrm{MAP}) ; \mathrm{L} 150$-Air $=$ burrata with $150 \mathrm{mg} / \mathrm{kg}$ of lysozyme packaged in air; L250-Air = burrata with $250 \mathrm{mg} / \mathrm{kg}$ of lysozyme packaged in air; L500-Air = burrata with $500 \mathrm{mg} / \mathrm{kg}$ of lysozyme packaged in air; L150-MAP = burrata with 150 $\mathrm{mg} / \mathrm{kg}$ of lysozyme packaged under MAP; L250 = burrata with $250 \mathrm{mg} / \mathrm{kg}$ of lysozyme packaged under MAP; L500 = burrata with $500 \mathrm{mg} / \mathrm{kg}$ of lysozyme packaged under MAP.

atmospheric and MAP conditions. The most striking feature is the lack of a proportional relation between lysozyme concentration and antimicrobial effect, according to other works in the literature dealing with the use of natural compounds and MAP (Del Nobile et al., 2009c; Conte et al., 2009b). The values of all calculated model parameters show that no specific trend can be obtained by varying lysozyme concentration and headspace conditions. The values of $\mathrm{MAL}^{\text {Coliforms }}$ reported in Table 1 in the CON-Air, CON-MAP, and L150-Air samples were not statistically different. Better results in MAL coliforms were recorded for L150 and L250 burrata cheese packaged under MAP, thus confirming the action of optimal gas and lysozyme concentrations on product quality. Although several authors have assessed the efficacy of MAP on coliform proliferation in milk-derived products (Maniar et al., 1994; Manneheim and Soffer, 1996; Eliot et al., 1998), limited effects on dairy foods have been demonstrated by using natural compounds of animal or plant origin during cheese making (Altieri et al., 2005; Gammariello et al., 2010).

Enterobacteriaceae (data not shown) showed a behavior similar to other microbial groups, with cell loads that accounted for $10^{8} \mathrm{cfu} / \mathrm{g}$ for both controls and $10^{6} \mathrm{cfu} / \mathrm{g}$ for all the burrata samples containing lysozyme $/ \mathrm{Na}_{2}$-EDTA. The combination of MAP and active substance also reduced the microbial proliferation of mesophilic and psychrotrophic bacteria (data not shown) by about 2 logarithmic cycles, compared with all samples sealed under atmospheric conditions. According to other works dealing with packaged dairy foods, no molds were recorded and concentrations of yeasts remained very low in all burrata cheeses (from $10^{2}$ to $10^{4} \mathrm{cfu} / \mathrm{g}$ ) throughout the entire storage period (Coppola et al., 1988; Conte et al., 2009a). With regard to lactic acid bacteria (data not shown), the cell loads were found to be similar in all samples, without any significant influence of the active compound or MAP on microbial proliferation. These results are in accordance with those recorded in fior di latte and stracciatella cheese packaged under MAP (Conte et al., 2009a; Gammariello et al., 2009)

With regard to $\mathrm{pH}$ (data not shown), a similar trend was recorded for all samples stored in air and under MAP, with values ranging around 6 throughout the observation period. Equally, no relevant observations can be made in terms of headspace gas composition; all samples under MAP maintained the initial headspace composition $\left(95 \% \mathrm{CO}_{2}\right)$ during the entire observation period, most probably because of the high barrier properties of the package. On the other hand, gas composition under atmospheric conditions changed substantially because microbial growth provoked a significant $\mathrm{O}_{2}$ depletion and an increment of $\mathrm{CO}_{2}$ that accounted for more than $20 \%$ at the end of the storage time. As examples of trends recorded for headspace gas conditions during storage, the 2 control samples are shown in Figure 3. All the other products in air and under MAP highlighted the same behavior reported in Figure 3, suggesting that no influence on gas was exerted by addition of lysozyme $/ \mathrm{Na}_{2}$-EDTA. These findings suggest that the high concentration of $\mathrm{CO}_{2}$ used during sealing and the very low level of $\mathrm{O}_{2}$ maintained in the package, combined with lysozyme $/ \mathrm{Na}_{2}$-EDTA in the product, are the main factors for effective packaging solutions (Conte et al., 2009a).

\section{Sensory Quality}

Figure 4 shows the evolution during storage of the overall quality of burrata cheese. The curves in the figures were obtained by fitting Eq. [2] to the experi- 

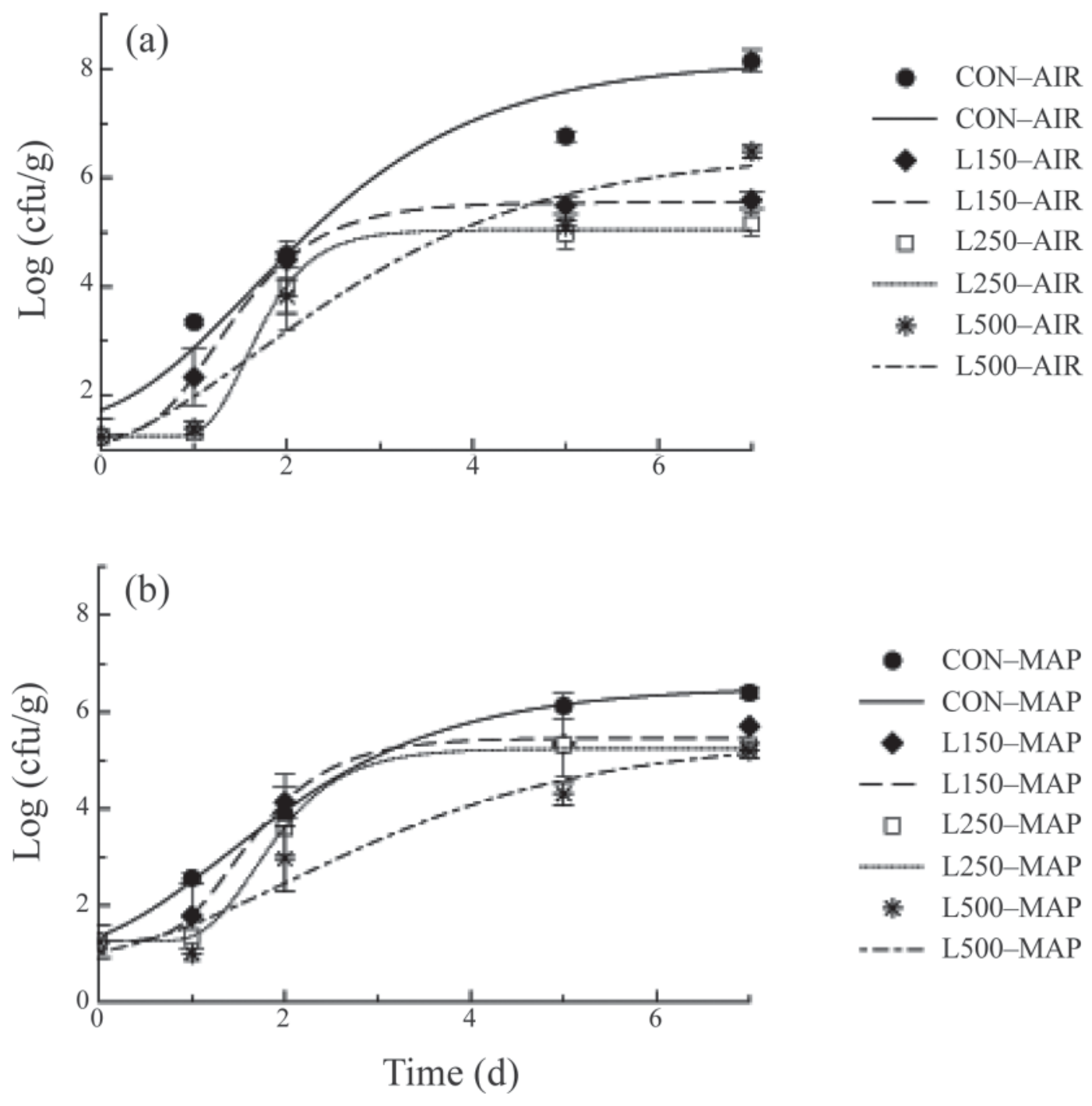

Figure 2. Total coliform cell concentrations in burrata cheese packaged (a) in air and (b) under modified-atmosphere packaging (MAP) during the storage period. CON-Air $=$ control in air; CON-MAP $=$ control under modified-atmosphere packaging $(\mathrm{MAP}) ; \mathrm{L} 150-\mathrm{Air}=$ burrata with $150 \mathrm{mg} / \mathrm{kg}$ of lysozyme packaged in air; L250-Air = burrata with $250 \mathrm{mg} / \mathrm{kg}$ of lysozyme packaged in air; L500-Air = burrata with 500 $\mathrm{mg} / \mathrm{kg}$ of lysozyme packaged in air; L150-MAP = burrata with $150 \mathrm{mg} / \mathrm{kg}$ of lysozyme packaged under MAP; L250 = burrata with $250 \mathrm{mg} /$ $\mathrm{kg}$ of lysozyme packaged under MAP; L500 = burrata with $500 \mathrm{mg} / \mathrm{kg}$ of lysozyme packaged under MAP. Data are presented with standard deviations; the curves are the best fit to the experimental data.

mental data. As expected, the quality of the tested cheese steadily decreased with time, regardless of the packaging strategy adopted (Gammariello et al., 2008). Two relevant aspects are evident. The first is the lack of substantial differences between samples. In fact, sensory acceptability in all burrata cheeses was preserved until $5 \mathrm{~d}$ under both atmospheric and MAP conditions. The discussion on sensory quality is not simple because of the limited availability of works dealing with MAP effects on sensory attributes of dairy foods. As in the current work, Conte et al. (2009a) found that an active coating loaded with lysozyme/ $\mathrm{Na}_{2}$-EDTA applied to fior di latte before packaging under MAP did not improve the sensory acceptability of product compared with a traditional packaging system. On the contrary, MAP conditions positively affected sensory quality of stracciatella (Gammariello et al., 2009). The second notable feature of Figure 4 is that, contrary to the microbiological results, slightly better acceptability was observed in both control samples compared with the burrata with active compounds. Burrata consistency was the parameter that most significantly affected product acceptability. Therefore, we could hypothesize that the addition of lysozyme $/ \mathrm{Na}_{2}$-EDTA, more than 

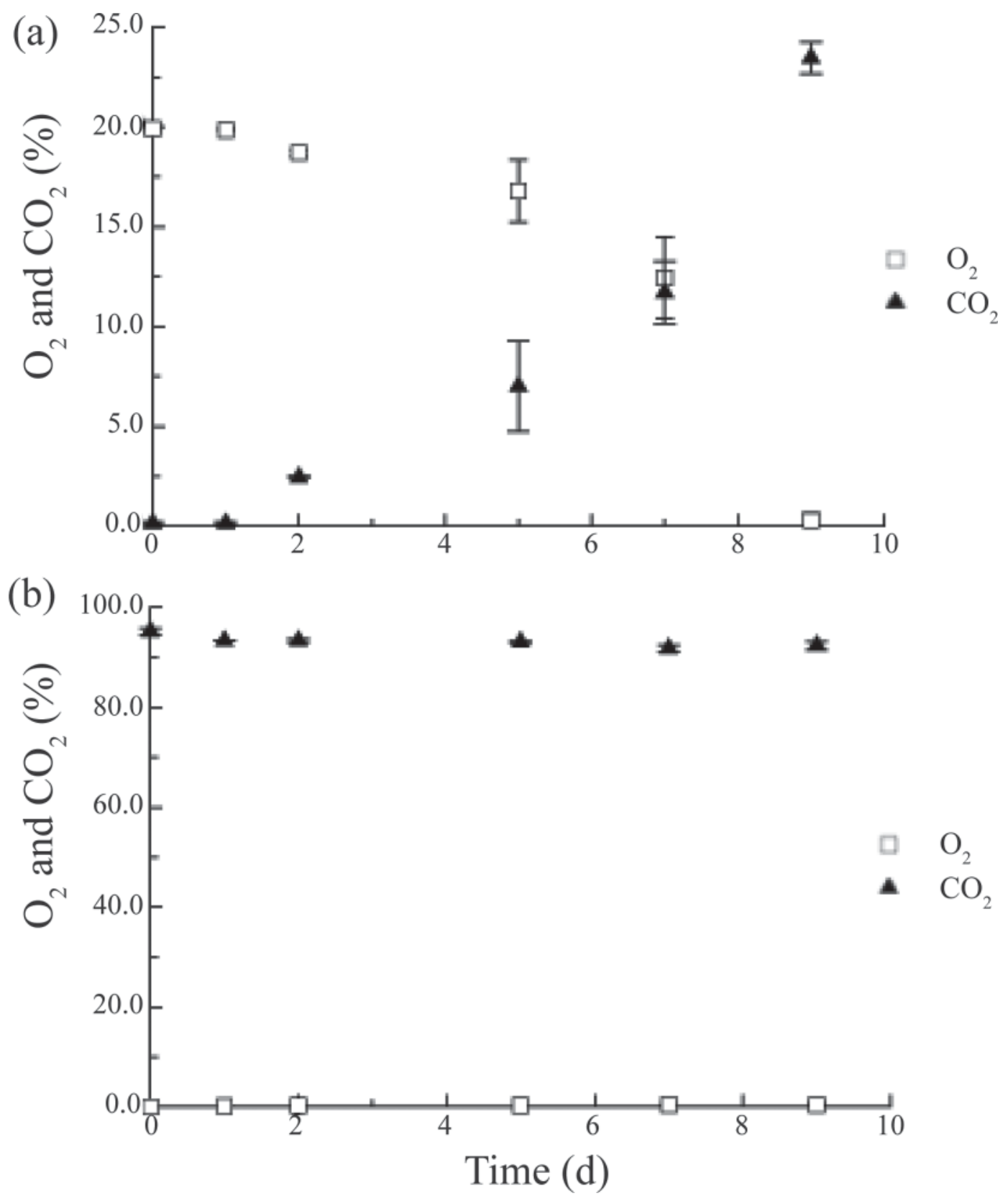

Figure 3. Evolution of oxygen and carbon dioxide in the control samples packaged (a) in air and (b) under modified-atmosphere packaging (MAP). Data are presented with standard deviations.

MAP, could affect texture characteristics and consequently the overall quality of burrata samples, as can be seen from SAL values reported in Table 1.

\section{Shelf-Life Evaluation}

According to Corbo et al. (2008), whenever the overall quality of a given product depends on several quality subindices, the shelf life of the packaged product is, by definition, the time at which one of the product quality subindices reaches its threshold value. In the case under investigation, the shelf life of each tested sample was calculated as the lowest value among the MAL ${ }^{\text {Pseudomo- }}$ nas, MAL ${ }^{\text {Coliforms }}$, and SAL values (Table 1). Microbial quality was responsible for unacceptability of burrata cheese in all samples, except for sample L500-MAP, where the sensory quality limited product shelf life. No statistically significant differences were observed between the CON-Air and CON-MAP samples. With regard to the samples with antimicrobial substance 

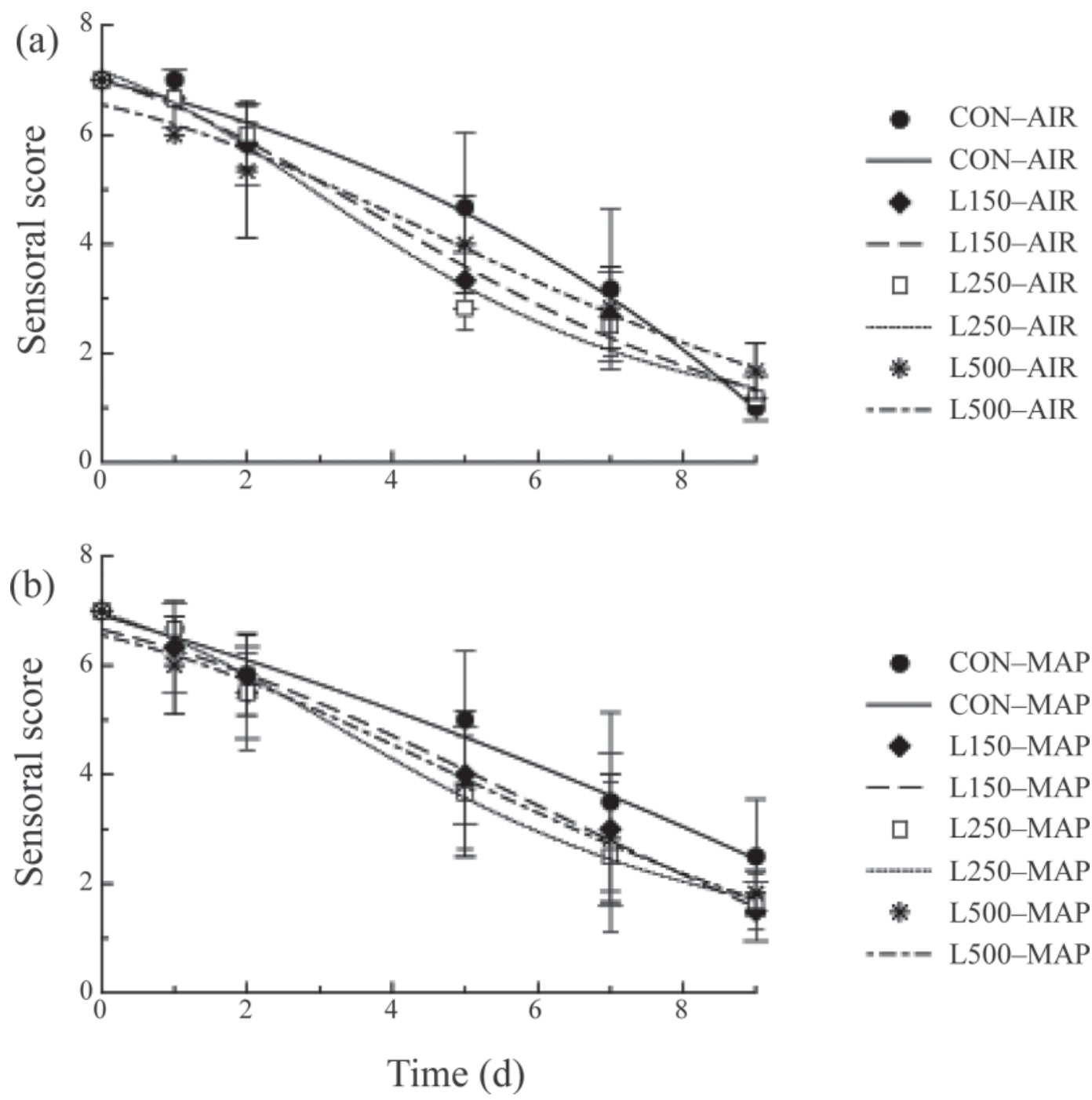

Figure 4. Sensory quality of burrata cheese packaged (a) in air and (b) under modified-atmosphere packaging $(\mathrm{MAP})$. CON-Air $=$ control in air; CON-MAP = control under modified-atmosphere packaging (MAP); L150-Air = burrata with $150 \mathrm{mg} / \mathrm{kg}$ of lysozyme packaged in air; L250Air = burrata with $250 \mathrm{mg} / \mathrm{kg}$ of lysozyme packaged in air; L500-Air = burrata with $500 \mathrm{mg} / \mathrm{kg}$ of lysozyme packaged in air; L150-MAP = burrata with $150 \mathrm{mg} / \mathrm{kg}$ of lysozyme packaged under MAP; L250 = burrata with $250 \mathrm{mg} / \mathrm{kg}$ of lysozyme packaged under MAP; L500 = burrata with $500 \mathrm{mg} / \mathrm{kg}$ of lysozyme packaged under MAP. Data are presented with standard deviations; the curves are the best fit to the experimental data.

stored in air, an insignificant increase in shelf life was observed compared with the controls. In contrast, the use of MAP combined with the antimicrobial substance increased burrata shelf life; the important effects of MAP and lysozyme/ $\mathrm{Na}_{2}$-EDTA on microbial spoilage counterbalanced the enzyme influences on sensory attributes, thus resulting in a prolongation of shelf life.

\section{CONCLUSIONS}

Lysozyme/ $\mathrm{Na}_{2}$-EDTA, combined with the sealing of product under MAP, can be used to prolong the shelf life of burrata cheese. In particular, the combination of these strategies can improve microbial stability, which appears to be the main factor responsible for burrata unacceptability. Results are in agreement with literature data on the antimicrobial properties of lysozyme and $\mathrm{Na}_{2}$-EDTA and confirmed the effects of MAP on dairy foods. In addition, the current work contributes to the dairy sector with specific information on the amount of enzyme to be used during cheese making and on gas combinations that could prevent microbial proliferation without compromising sensory attributes. The feasibility of strategies proposed in this work could be promoted at an industrial level to produce burrata with longer shelf life. 


\section{ACKNOWLEDGMENTS}

This work was financially supported by Project LEGGE 297/99 (Tecnologie per il Packaging Bioattivo di Prodotti Lattiero Caseari Freschi Pugliesi DM 29040).

\section{REFERENCES}

Altieri, C., C. Scrocco, M. Sinigaglia, and M. A. Del Nobile. 2005. Use of chitosan to prolong Mozzarella cheese shelf life. J. Dairy Sci. 88:2683-2688.

Alves, R. M. V., C. I. G. Sarantopoulos, A. G. F. Van Dender, and J. A. F. Faria. 1996. Stability of sliced Mozzarella cheese in modified atmosphere packaging. J. Food Prot. 59:838-844.

Boland, J. S., P. M. Davidson, and J. Weiss. 2003. Enhanced inhibition of Escherichia coli O157:H7 by lysozyme and chelators. J. Food Prot. 66:1783-1789.

Branen, J. K., and P. M. Davidson. 2004. Enhancement of nisin, lysozyme, and monolaurium antimicrobial activities by ethylenediaminetetraacetic acid and lactoferrin. Int. J. Food Microbiol. 90:63-74.

Conte, A., D. Gammariello, S. Di Giulio, M. Attanasio, and M. A. Del Nobile. 2009a. Active coating and modified-atmosphere packaging to extend the shelf life of Fior di Latte cheese. J. Dairy Sci. 92:887-894.

Conte, A., C. Scrocco, M. Sinigaglia, and M. A. Del Nobile. 2007. Innovative active packaging system to prolong the shelf life of Mozzarella cheese. J. Dairy Sci. 90:2126-2131.

Conte, A., C. Scrocco, M. Sinigaglia, and M. A. Del Nobile. 2009b. Lemon extract as natural preservative in fruit salad. J. Food Saf. 29:601-616.

Coppola, R., E. Parente, S. Dumontet, and A. Peccerella. 1988. The microflora of natural whey cultures utilized as starters in the manufacture of Mozzarella cheese from water-buffalo milk. Lait 68:295-310.

Corbo, M. R., B. Speranza, A. Filippone, S. Granatiero, A. Conte, M. Sinigaglia, and M. A. Del Nobile. 2008. Study on the synergic effect of natural compounds on the microbial quality decay of packaged fish hamburger. Int. J. Food Microbiol. 127:261-267.

Corradini, C., and N. Innocente. 2002. Parametri chemiometrici e descrittori sensoriali del Montasio DOP. Notiziario Ersa 4/2002:4345.

Crapisi, A., A. Lante, G. Pasini, and P. Spettoli. 1993. Enhanced microbial cell lysis by the use of lysozyme immobilized on different carrier. Process Biochem. 28:17-21.

Daniels, A. J., R. Krishnamurthi, and S. S. H. Rizvi. 1985. A review of effects of carbon dioxine on microbial growth and food quality. J. Food Prot. 48:532-537.

Del Nobile, M. A., A. Conte, M. Cannarsi, and M. Sinigaglia. 2009c. Strategies for prolonging the shelf life of minced beef patties. J. Food Saf. 29:14-25.
Del Nobile, M. A., A. Conte, A. L. Incoronato, and O. Panza. 2009a. Modified atmosphere packaging to improve the microbial stability of Ricotta. African J. Microbiol. Res. 3:137-142.

Del Nobile, M. A., D. Gammariello, A. Conte, and M. Attanasio. 2009b. A combination of chitosan, coating and modified atmosphere packaging for Fior di Latte cheese. Carbohydr. Polym. 78:151-156.

Eliot, S. C., J. C. Vuillemard, and J. P. Emond. 1998. Stability of shredded mozzarella cheese under modified atmospheres. J. Food Sci. $63: 1075-1080$.

Farber, J. M. 1991. Microbiological aspects of modified atmosphere packaging technology: A review. J. Food Prot. 54:58-70.

Floros, J. D., P. V. Nielsen, and J. K. Farkas. 2000. Advances in modified atmosphere and active packaging with applications in the dairy industry. Packaging of Milk Products. IDF Bull. 346:22-28. Int. Dairy Federation, Brussels, Belgium.

Gammariello, D., A. Conte, M. Attanasio, and M. A. Del Nobile. 2010. Study on the combined effects of essential oils on microbiological quality of Fior di Latte cheese. J. Dairy Res. 77:144-150.

Gammariello, D., A. Conte, S. Di Giulio, M. Attanasio, and M. A. Del Nobile. 2009. Shelf life of stracciatella cheese under modified atmosphere packaging. J. Dairy Sci. 92:483-490.

Gammariello, D., S. Di Giulio, A. Conte, and M. A. Del Nobile. 2008 Effects of natural compounds of microbial safety and sensory quality of Fior di Latte cheese, a typical Italian cheese. J. Dairy Sci. 91:4138-4146.

Gonzalez-Fandos, E., S. Sanz, and C. Olarte. 2000. Microbiological, physicochemical and sensory characteristics of Cameros cheese packaged under modified atmospheres. Food Microbiol. 17:407414.

Maniar, A. B., J. E. Marcy, J. Russell-Bishop, and S. E. Duncan. 1994. Modified atmosphere packaging to maintain direct-set cottage cheese quality. J. Food Sci. 59:1305-1308.

Manneheim, C. H., and T. Soffer. 1996. Shelf-life extension of cottage cheese by modified atmosphere packaging. Lebenson. Wiss. Technol. 29:767-771.

Masschalck, B., and C. W. Michiels. 2003. Antimicrobial properties of lysozyme in relation to food-borne vegetative bacteria. Crit. Rev. Microbiol. 29:191-214.

Moir, C. J., M. J. Eyles, and J. A. Davey. 1993. Inhibition of Pseudomonas in cottage cheese by packaging in atmospheres containing carbon dioxide. Food Microbiol. 10:345-351.

Papaioannou, G., I. Chouliara, A. E. Karatapanis, M. G. Kontominas, and I. N. Savvaidis. 2007. Shelf life of a Greek whey cheese under modified atmosphere packaging. Int. Dairy J. 17:358-364.

Salvadori del Prato, O. 2001. Trattato di tecnologia casearia. Calderoni Ed. Agricole, Bologna, Italy.

Sinigaglia, M., A. Bevilacqua, M. R. Corbo, S. Pati, and M. A. Del Nobile. 2008. Use of active compounds for prolonging the shelf life of mozzarella cheese. Int. Dairy J. 18:624-630. 